\title{
Simulium (Psaroniocompsa) tergospinosum New Species (Diptera: Simuliidae) in siolii Group from the Southern Part of the State of Amazonas, Brazil
}

\author{
Neusa Hamada \\ Coordenação de Pesquisas em Entomologia, Instituto Nacional de Pesquisas da Amazônia, Caixa Postal 478, \\ 69011-970 Manaus, AM, Brasil
}

The larva, pupa, male and female of Simulium tergospinosum $n$. sp. are described and illustrated. The adults of this new species share many characters with species in the subgenus Psaroniocompsa, where it is placed. The larva of this species bears dorsal and lateral triangular tubercles on the abdomen and multiply branched scale-like setae on the body, suggesting that it belongs to the $\mathrm{S}$. siolii species group. S. tergospinosum n.sp. was collected along the Juma River, Apui county, in the southern part of the State of Amazonas, Brazil. The Juma, a black-water river, is a tributary of the Aripuanã River in the Madeira River hydrographic basin, on the southern part of Amazonas. Females were collected biting humans along the water courses during the sampling period (in the dry season).

Key words: aquatic insects - black fly - Simuliidae - Simulium - Amazonas - Brazil

Crosskey and Howard's (1997) world black fly checklist presents five species groups in the subgenus Simulium (Psaroniocompsa): S. amazonicum, S. auristriatum, S. incrustatum, $S$. quadrifidum and $S$. siolii species groups), including in this subgenus 35 species. Coscarón and Coscarón-Arias (1997) did not consider the $S$. amazonicum and $S$. quadrifidum species groups to be included in Psaroniocompsa, considering them as subgenus, $S$. (Cerqueirellum) and $S$. (Coscaroniellum), respectively. Hamada and Adler (1998) described $S$. daltanhani, which is placed by Crosskey (1999) in the subgenus Psaroniocompsa, but for which the species group is unknown.

The siolii species group is composed of four species: S. siolii Py-Daniel, S. damascenoi PyDaniel, S. lourencoi Py-Daniel and S. guaporense Py-Daniel. This species group is characterized by the presence of dorsal and lateral triangular tubercles and dorsal, multiply branched scale-like setae on the larval body. In the present paper I describe the larva, pupa, and adult male and female of a new species in the $S$. siolii species group,

\footnotetext{
This study received partial financial support from PPI 1-3400 and PPI 1-3070 (MCT/INPA), Brazil Soka Gakkai International, and the Third World Academy of Sciences.

Fax: +55-92-642.8909. E-mail: nhamada@inpa.gov.br Received 14 December 1999

Accepted 22 March 2000
}

found in a tributary of the Aripuanã River, in the Madeira River hydrographic basin, in the southern part of State of Amazonas, Brazil.

\section{MATERIALS AND METHODS}

Larvae and pupae were collected at the Juma River, Apuí county, in the southern part of the State of Amazonas, Brazil, in 1998 (July and August) and 1999 (May and August). Larvae and pupae were fixed in Carnoy's solution (one part acetic acid: three parts absolute ethanol) and kept in a refrigerator. Before deposition of the specimens in the museum collection they were transferred to $80 \%$ ethanol. Some of the pupae were reared to adults, and then stored in $80 \%$ ethanol. Females biting humans during field work were stored in $80 \%$ ethanol. In the laboratory the adult specimens stored in $80 \%$ ethanol were treated wit ethyl glycol (Cellosolve) and xylol, according to the technique of Sabrosky (1966), to dehydrate; then they were pinned. Permanent slides were prepared using Euparal ${ }^{\circledR}$ as the mounting medium. When needed, structures were clarified in hot $95 \%$ lactic acid; genitalia, after being clarified, were stored in glycerin. Nomenclature follows that of Coscarón (1987).

Since the types of species in the siolii group were not available for loan to the author of the present paper, the comparisons among species in the group were based on the original description (Py-Daniel 1988, 1989). Specimens of the new species were compared with larvae and pupae of $S$. damascenoi, collected in the type locality region (Igarapé Davi Grande, August 1993; 
Cachoeira Grande, August 1993, July 1996, Col. N Hamada), State of Amapá, Brazil.

The holotype and paratypes are deposited in the Invertebrate Collection of Instituto Nacional de Pesquisas da Amazônia (INPA), Manaus, Amazonas, Brazil; other paratypes are deposited in the Clemson University Arthropod Collection (CUAC), Clemson University, SC, USA, and at the Natural History Museum (NHM), London, England. Voucher specimens of other species examined are deposited at the first institution.

\section{DESCRIPTION}

Simulium (Psaroniocompsa) tergospinosum n. sp.

Male: general body color black; body length: 1.3$1.9 \mathrm{~mm}(\overline{\mathrm{x}}=1.8 \mathrm{~mm}, \mathrm{n}=7)$; lateral thorax length: $0.48-0.5 \mathrm{~mm}(\overline{\mathrm{x}}=0.5 \mathrm{~mm}, \mathrm{n}=7)$. Wing length: $\overline{\mathrm{x}}$ $=1.7 \mathrm{~mm}(\mathrm{n}=5)$; width: $\overline{\mathrm{x}}=0.8 \mathrm{~mm}(\mathrm{n}=5)$. Frons, clypeus and occiput with silvery, blue pruinosity. Antenna: $0.41-0.47 \mathrm{~mm}(\overline{\mathrm{x}}=0.44 \mathrm{~mm}$, $\mathrm{n}=9$ ) in length; pedicel and scape brownish yellow, flagellum dark brown (Fig. 1). Palpus (Fig. 2) dark brown, palpomere $\mathrm{V}$ about 1.9 times as long as palpomere III and 1.8 times as long as palpomere IV; sensory vesicle small, subspherical. Scutum black, with golden reddish hairs, unevenly distributed; one pair of silver, sub-median cunei- form bands (Figs 3, 4). Scutellum brown, postnotum brown with silver pruinosity. Anepisternum and katepisternum dark brown. Wing veins yellowish brown; spines and setae brown; Sc and base of $\mathrm{R}$ bare (Fig. 5). Halter with basal region dark brown and terminal region whitish. Foreleg (Fig. 17) with coxa, trochanter, femur and tibia pale yellowish brown, all tarsal segments black. Middle leg (Fig. 18) with coxa, trochanter, femur and tibia light brown and all tarsal segments pale yellowish brown. Hind leg (Fig. 19) with femur, tibia and 5th tarsomere distally pale yellowish brown and dark brown apically; the other tarsal segments pale yellowish brown. Tarsal claws without lobe (Fig. 20). Calcipala as broad as long, reaching pedisulcus (Fig. 21). Femora and tibiae with scalelike setae distributed with filiform ones (Fig. 22). Abdominal tergites dark brown, basal fringe with thin, long, brown hairs and golden highlights; tergite II with silvery blue pruinosity; tergites V-VIII with silver pruinosity forming band laterally. Gonocoxite and gonostylus brown (Figs 6, 7); gonostylus bearing one apical tooth and one longitudinal ridge (Fig. 8). Ventral plate as in Fig. 9, in ventral view. Median sclerite (Fig. 10) sub-oval with small, medial concavity. Paramere (Fig. 11) with spines.

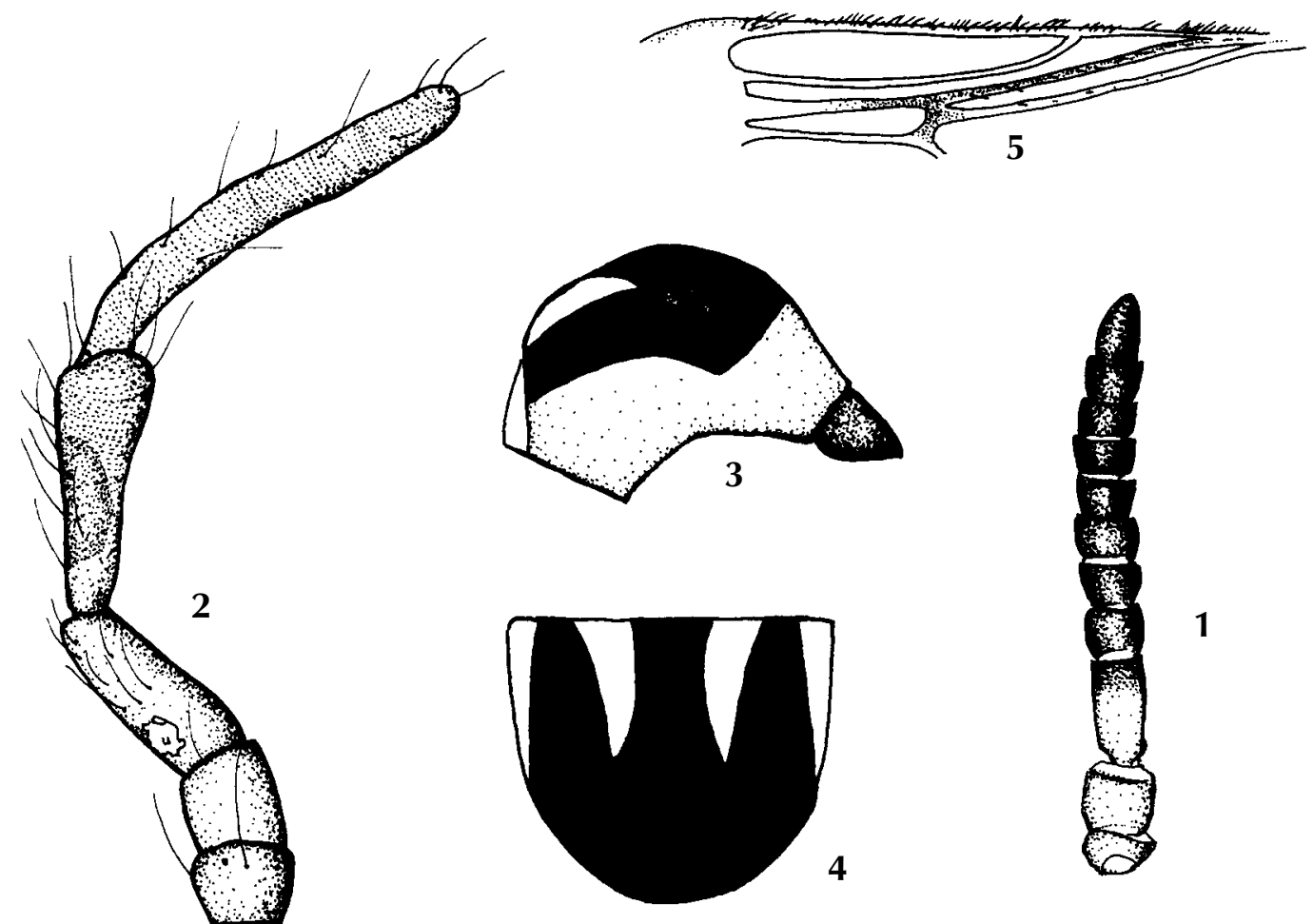

Simulium tergospinosum, male. Fig. 1: antenna. Fig. 2: maxillary palpus. Scutum. Fig. 3: lateral view. Fig. 4: dorsal view. Fig. 5: wing 
Female: general body color black; body length: 1.5 $1.8 \mathrm{~mm}(\overline{\mathrm{x}}=1.65 \mathrm{~mm}, \mathrm{n}=9)$; lateral thorax length: $0.62-0.71 \mathrm{~mm}(\bar{x}=0.59 \mathrm{~mm}, \mathrm{n}=9)$. Wing length: 1.71-1.78 mm ( $\bar{x}=1.7 \mathrm{~mm}, \mathrm{n}=6)$; width: $0.83-$ $0.98 \mathrm{~mm}(\bar{x}=0.89 \mathrm{~mm}, \mathrm{n}=6)$. Frons, clypeus and occiput with silvery blue pruinosity; frons longer than wide; fronto-ocular suture small (Fig.
12); fronto-ocular triangle almost absent (Fig. 12). Antenna length: $0.46-0.52 \mathrm{~mm}(\overline{\mathrm{x}}=0.49 \mathrm{~mm}, \mathrm{n}=$ 7 ), with silver pubescence; pedicel, scape and first flagellomere pale yellowish brown, following flagellomeres increasingly dark brown (Fig. 13). Palpus dark brown; sensory vesicle small, with short neck (Fig. 14), palpomere V 2.1 times as long

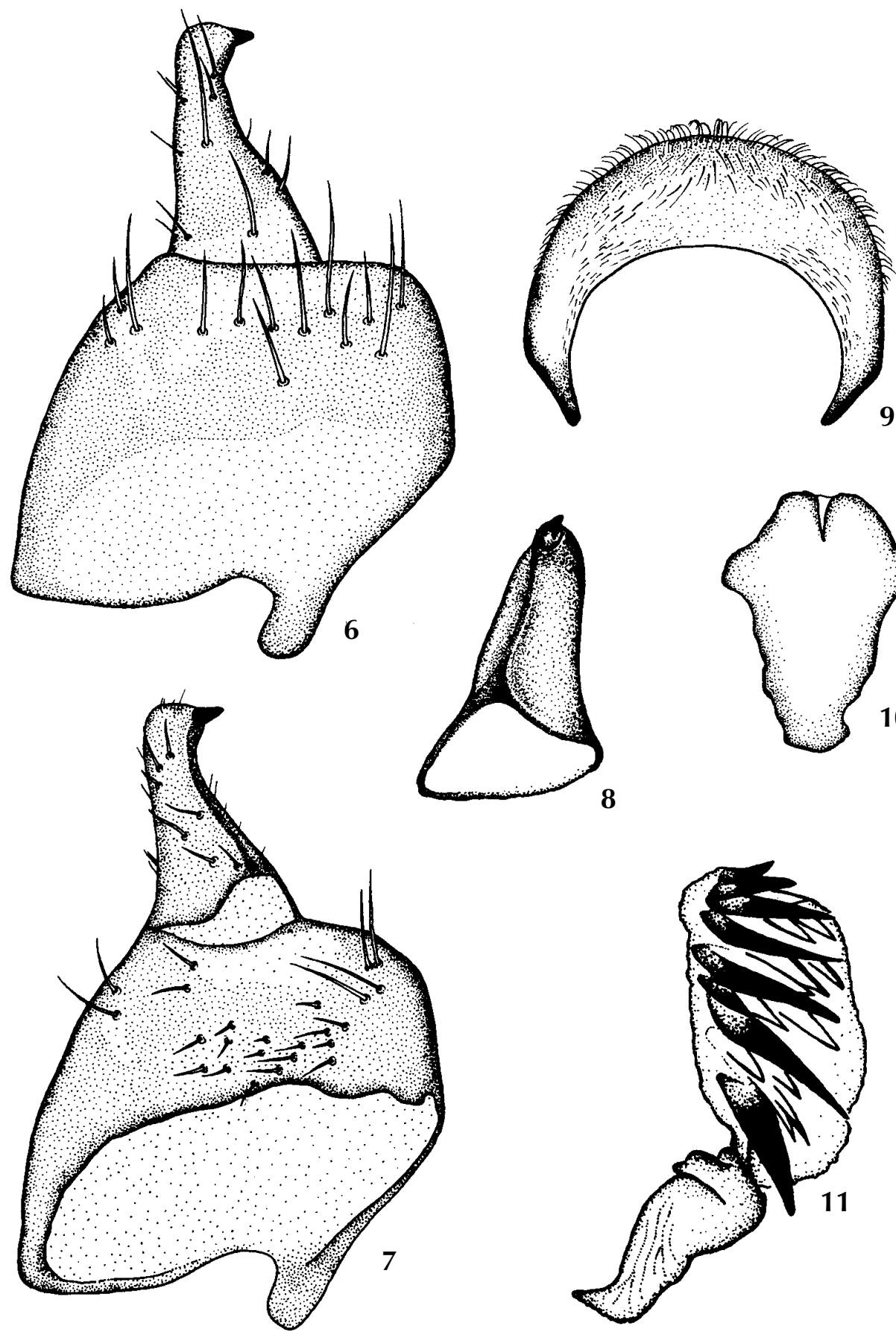

Simulium tergospinosum, male. Gonocoxite and gonostylus. Fig. 6: dorsal view. Fig. 7: ventral view. Fig. 8: gonostylus, ventral view. Fig. 9: ventral plate, ventral view. Fig. 10: median sclerite. Fig. 11: paramere 
as palpomere III and 1.7 times as long as palpomere IV. Mandible with 22-27 external serrations and 4-8 internal teeth. Lacinia with 17-26 retrorse teeth. Medial region of cibarium with rounded or blunted projections, surrounded by sharp teeth (Fig. 15). Scutum black with thin, golden reddish hairs, unevenly distributed; two thick silver stripes (Fig. 16). Anepisternum and katepisternum dark brown, with silver pruinosity. Scutellum brown, with brown hairs; postnotum brown with silver pruinosity. Wing veins yellowish brown; setae and spines brown; Sc and base of R bare. Halter and legs with same color pattern as male. Abdominal sclerites brown, with long, black setae on terminal tergites; membranous areas greenish, especially in live specimens. Basal fringe with thin, brown hairs, highlighted with gold. Tergite II with silvery blue pruinosity; tergites VI-VIII with a varnish-like appearance. In lateral view, cercus round, anal lobe subtriangular (Fig. 23); hypogynial lobes (Fig. 24) subtriangular, with abundant microtrichia, internal marginal area sclerotized, with setae. Genital fork
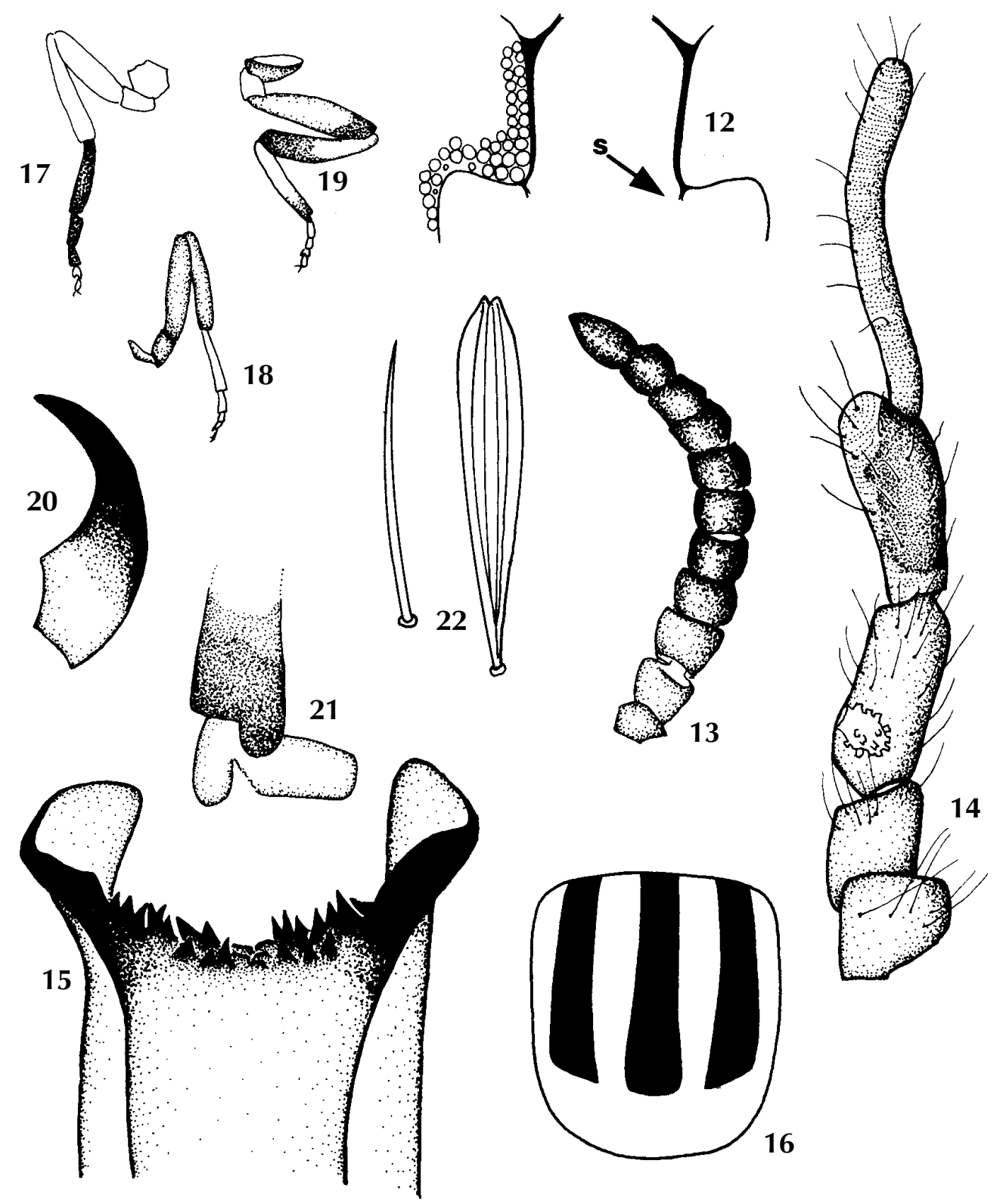

Simulium tergospinosum, female. Fig. 12: fronto-ocular triangle, s: frontal suture. Fig. 13: antenna. Fig. 14: maxillary palpus. Fig. 15: cibarium. Fig. 16: scutum, dorsal view. Fig. 17: fore leg. Fig. 18: middle leg. Fig. 19: hind leg. Fig. 20: tarsal claw. Fig. 21: filiform and scale-like setae from legs. Fig. 22: calcipala and pedisulcus 
(Fig. 25) with stem moderately long and slender, lateral arms forming a suboval space in region of bifurcation. Spermatheca subspherical, with cuticular microspines; spermathecal duct and area of attachment unpigmented.

Pupa-length: $1.8-2 \mathrm{~mm}(\overline{\mathrm{x}}=1.9 \mathrm{~mm}, \mathrm{n}=3)$. Cocoon (Fig. 26) slipper-shaped; without anterior projection; individual threads distinctly perceptible; anterior margin reinforced. Color of cocoon light brown. Length along dorsal surface $2.3 \mathrm{~mm}$; lateral surface $2.8 \mathrm{~mm}$. Head projecting downward, with three pairs of trichomes; two frontal pairs simple, and one dorsal pair bifid or trifid. Head without defined tubercles (Fig. 28). Gills $2 \mathrm{~mm}$ long, with four anteriorly directed filaments, two short primary petioles, each giving rise to two divergent filaments (Fig. 30), usually the two dorsal filaments branch near the base and they are thicker than the two ventral one. Thorax anteriorly without tubercles, posteriorly with rounded or pointed tubercles; five pairs of simple-quadrifid trichomes and one pair of simple-trifid lateral trichomes (Fig. 29). Abdomen as in Fig. 27.

Larva (final instar): Figs 31, 32. Length: 4.3-4.6 $\mathrm{mm}(\overline{\mathrm{x}}=4.3 \mathrm{~mm}, \mathrm{n}=5)$; head capsule lateral length: $0.31 \mathrm{~mm}(\overline{\mathrm{x}}=0.31 \mathrm{~mm}, \mathrm{n}=5)$, dorsal width: $0.43 \mathrm{~mm}(\overline{\mathrm{x}}=0.43 \mathrm{~mm}, \mathrm{n}=4)$. General colora- tion green, some dark blue (in Carnoy's solution). Head capsule (in dorsal view) with light positive spots (Fig. 35), with small simple setae. Cervical sclerites small, eliptical, free in membrane. Postgenal cleft (Fig. 36) rounded, widest at base and midpoint, postgenal bridge 0.48 times as long as hypostoma. Subesophageal ganglion pigmented (Fig. 36). Antenna (Fig. 34) longer than labralfan stalk; distal, medial and proximal articles of similar size (proportions of articles, proximal to distal, excluding apical sensillum, 1:0.8-1.2:1-1.1). Hypostoma (Fig. 37) median tooth with same size of lateral teeth; two paralateral teeth; 4-7 lateral serrations and 4-5 setae (per side). Labral fan with 34-36 primary rays. One or two lateral mandibular processes, simple or bifid (Figs 38-40), reaching mandible inferior margin. Mandibular teeth: one apical, two external, three subapical - the third one shorter than second and both smaller than first one; 8-9 internal teeth; one large mandibular serration and one small mandibular sensillum (sensu Craig \& Craig 1986). Labral sclerite as in Fig. 41. Body covered with multiply branched scale-like setae (Fig. 33); intersegmental bands clear, distinct. Two pairs of triangular tubercles, one dorsal and one lateral, on segments II-VI (Figs. 31-32); paired dorsal triangular tubercles on VIIth segment (Figs

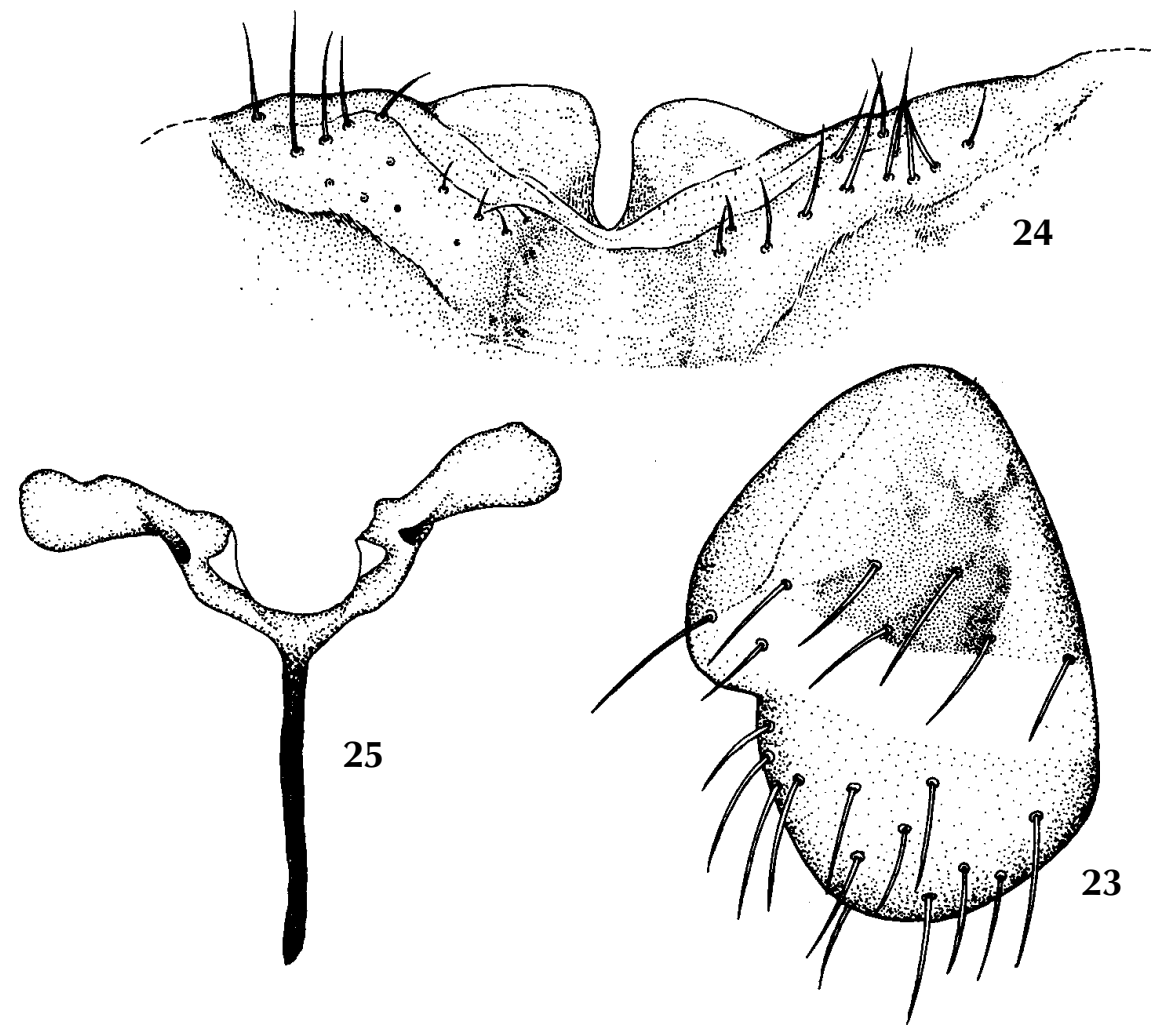

Simulium tergospinosum, female. Fig. 23: anal lobe and cercus, lateral view. Fig. 24: hypogynial lobe, ventral view. Fig. 25: genital fork 
31, 32). Paired, small, pointed ventral posterior tubercles present. Anterodorsal arms of anal sclerite (Fig. 42) thinner and shorter in length than posteroventral arms, associated with scale-like setae (Fig. 42). Posterior proleg bearing 62-69 rows $(\bar{x}=66, n=10)$ with $12-15$ hooks $(\bar{x}=13, n=$ 10). Anal papillae with three branches, each with 8-11 digitform lobes (Fig. 43).

Types. Holotype - pinned male, reared from pupae, collected at the Apuí waterfall, Juma River, Apuí county $\left(07^{\circ} 12^{\prime} \mathrm{S}, 59^{\circ} 54^{\prime} \mathrm{W}\right)$, Amazonas, Brazil, coll. FF Xavier Filho, 1-2/VIII/1998 (INPA). Paratypes - same locality, date and collector as holotype: 6 males (M), 8 females (F) pinned
(INPA), 1M, 1F pinned (CUAC); 1M,1F pinned (NHM); 5M, 7F mounted on slide and thorax pinned (INPA); 3 larvae in 80\% ethanol (CUAC); 2 larvae in $80 \%$ ethanol (NHM). Apuí waterfall, Juma River, Apuí County, Amazonas, Brazil, coll. N Hamada, 2/VII/1998: 7 pupae mounted on slide (INPA); 10 larva mounted on slide (INPA); 6 larvae in $80 \%$ ethanol (INPA); 4 pupae in $80 \%$ ethanol (CUAC); 4 pupae in $80 \%$ ethanol (NHM). Cachoeira Paredão, Juma River, Apuí county, Amazonas, Brazil, coll. N Hamada, 2/VII/1998: 5F pinned, biting humans (INPA). Igarapé Seringueira, Apuí county, Amazonas, Brazil, coll. N Hamada, 2/VII/1998: 1F pinned, biting humans
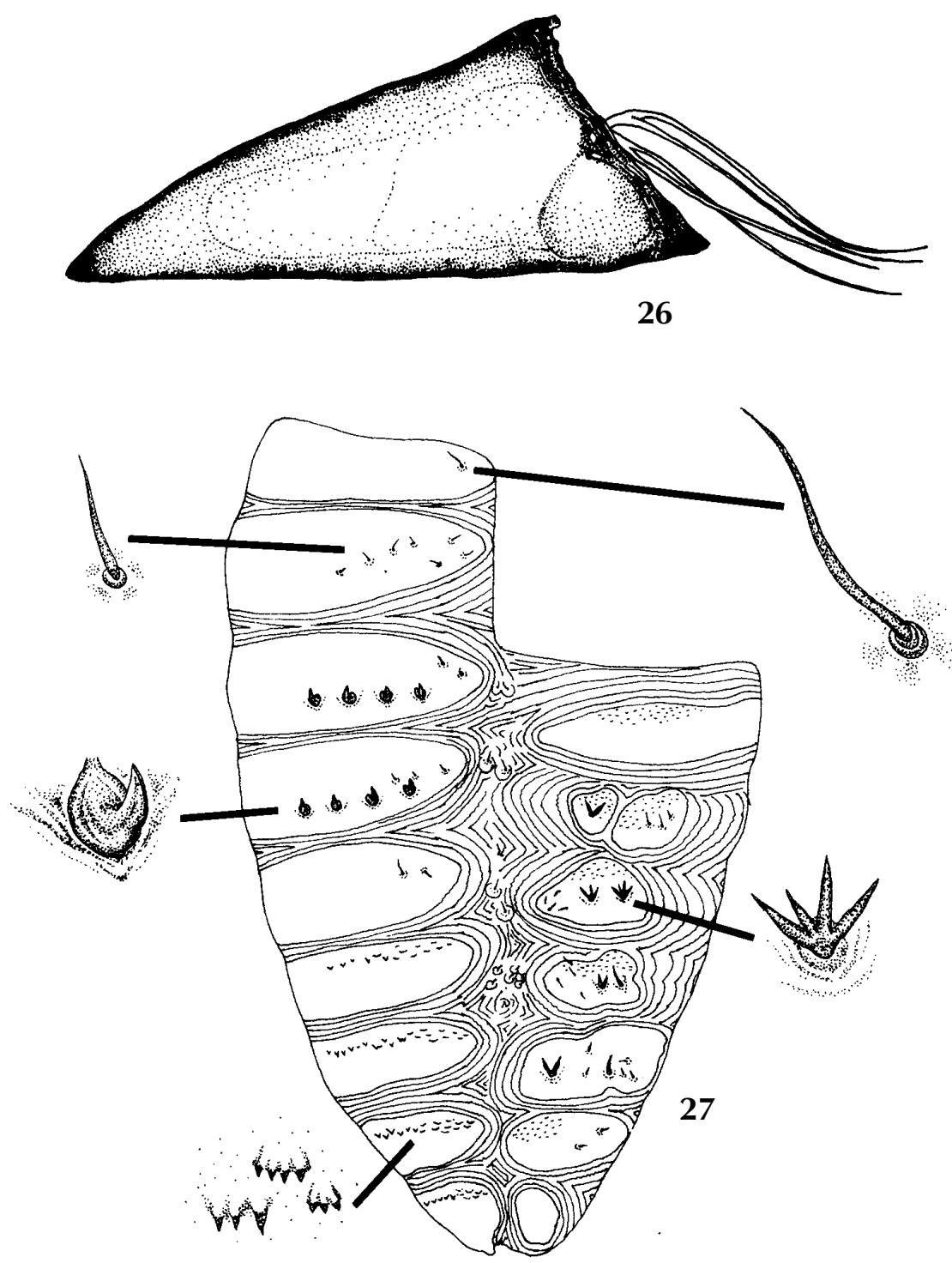

Simulium tergospinosum, pupa. Fig. 26: lateral view. Fig. 27: abdomen, dorsal (left side) and ventral (right side) view 
(INPA). Apuí waterfall, Juma River, Apuí county, Amazonas, Brazil, coll. N Hamada, 3/V/1999: 4 larvae and 10 pupae in $80 \%$ ethanol (INPA). Juma River, bridge on the Transamazônica road, $\sim 6 \mathrm{~km}$ far away from Apuí town, Apuí county, Amazonas, Brazil, coll. N Hamada, 29/VIII/1999: 10 larvae

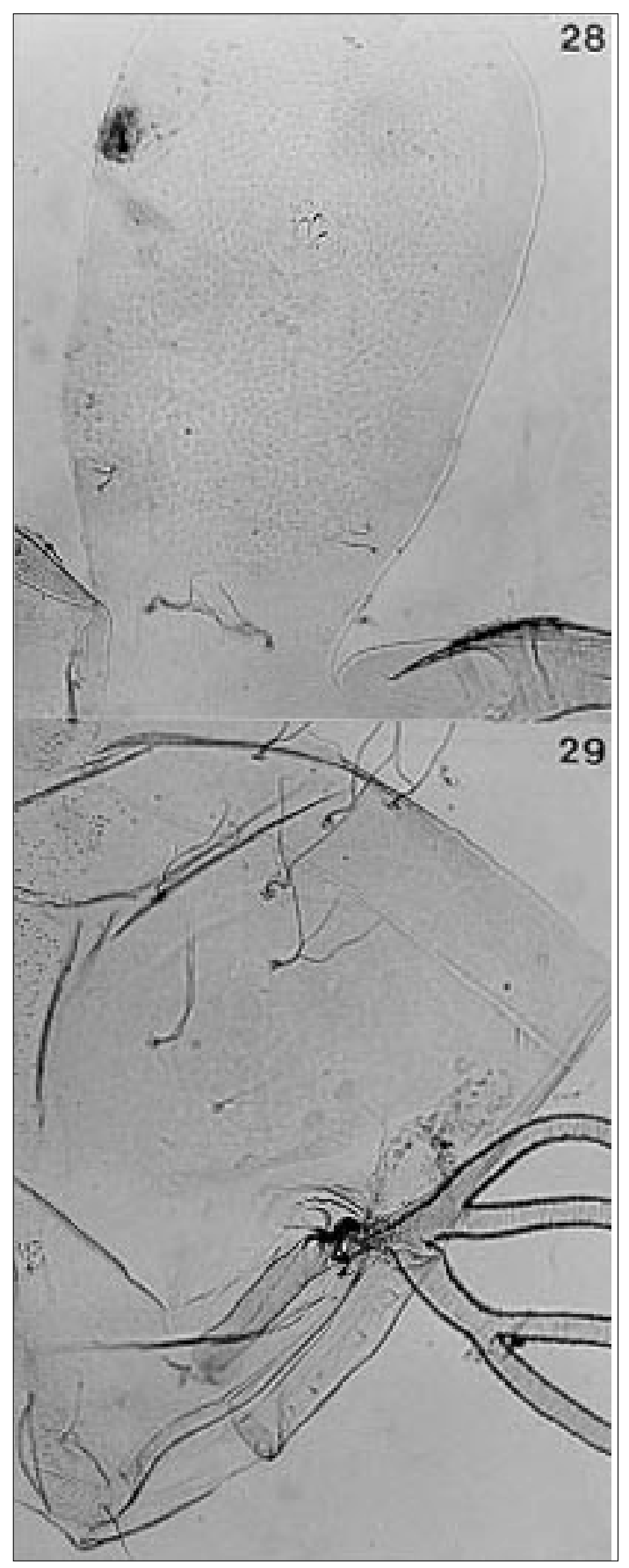

Simulium tergospinosum, pupa. Fig. 28: cephalic plate. Fig. 29: thorax and 12 pupae in $80 \%$ ethanol (INPA). Cachoeira Paredão, Juma River, Apuí county, Amazonas, Brazil, coll. N Hamada, 29/VIII/1999: 10F in $80 \%$ ethanol, biting humans (INPA).

Etymology: the name of this species refers to the characters of the larval body, which bears abdominal triangular tubercles. Tergo (L.) $=$ dorsal region; spinosum $(\mathrm{L})=$. spines, tubercles .

Diagnosis: S. tergospinosum larvae have dorsal and lateral triangular tubercles on the abdomen (Figs 31,32 ), a character shared, in the Neotropics, only with species in the S. siolii group. Last instar larvae in this species group have either four or six branchial filaments, seen after dissection of the histoblast (Py-Daniel 1988, 1989). S. guaporense can be distinguished from the new species by having six filaments and S. siolii and S. lourencoi by having the secondary filaments branching far away from the base. S. tergospinosum larvae can be distinguished from $S$. damascenoi by the presence of abdominal ventral tubercles and by the absence of the dorsal projection on the VIII abdominal tergum. The pupae of S. tergospinosum has four filament gills, but this species can be distinguished from others with four filament gills in the subgenus Psaroniocompsa, sensu Crosskey \& Howard (1997), such as S. siolii, S. lourencoi, S. quadrifidum Lutz, $S$. cauchense Floch \& Abonnenc and S. schmidtmummi Wygodzinsky, by having the filament length shorter than its cocoon, and/or by the secondary filaments branching near the base of the gills. S. venezuelense Ramírez-Pérez \& Peterson have the filament gills branching near the base, very similar to $S$. tergospinosum; however, the dorsal pair of trichomes on the head of the pupa of the first species is simple, while in $S$. tergospinosum they are bifid or trifid. The pupa of the new species (cocoon lateral length $=2.8 \mathrm{~mm}$, gill length $=2 \mathrm{~mm}$ ) is slightly bigger than that of $S$. damascenoi (cocoon lateral length $=2.3 \mathrm{~mm}$, gill length $=1.9 \mathrm{~mm}$ ); otherwise they are very similar. The female of $S$. tergospinosum can be distinguished from those of other species in the subgenus Psaroniocompsa (except females in the S. siolii group) by the thick, paired silver band on the notum. S. tergospinosum females have the same scutum pattern and genitalia shape as $S$. siolii, and have the same genitalia shape as $S$. damascenoi, the scutum pattern of which is unknown. The males of $S$. tergospinosum can be distinguished from males of other species in the subgenus Psaroniocompsa (with the exceptions of S. siolii and $S$. daltanhani) by the presence of a ridge extending from the basal to the apical region of the gonostylus. Of the four previously described species in the S. siolii group, S. siolii is the only one for which the males are known. Py-Daniel (1988) 


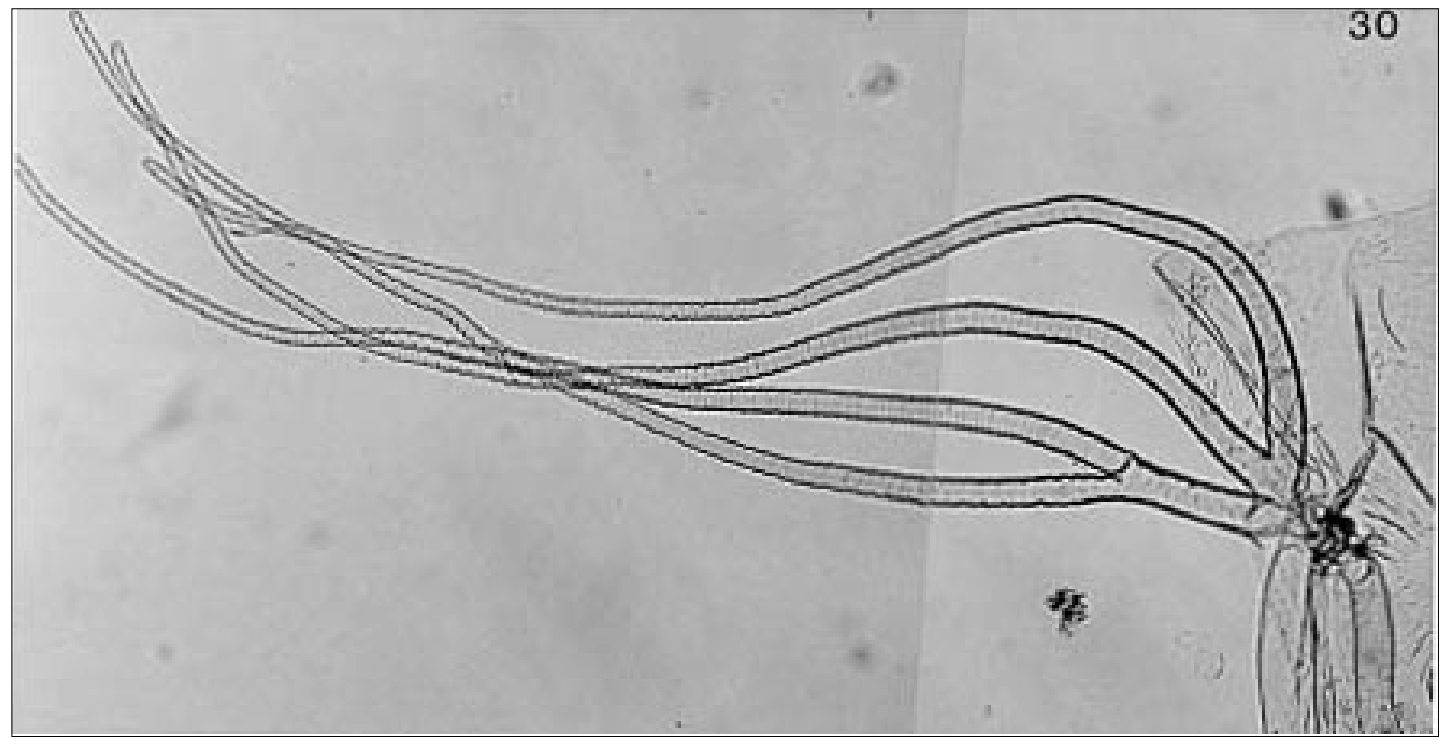

Simulium tergospinosum, pupa. Fig. 30: filament gills
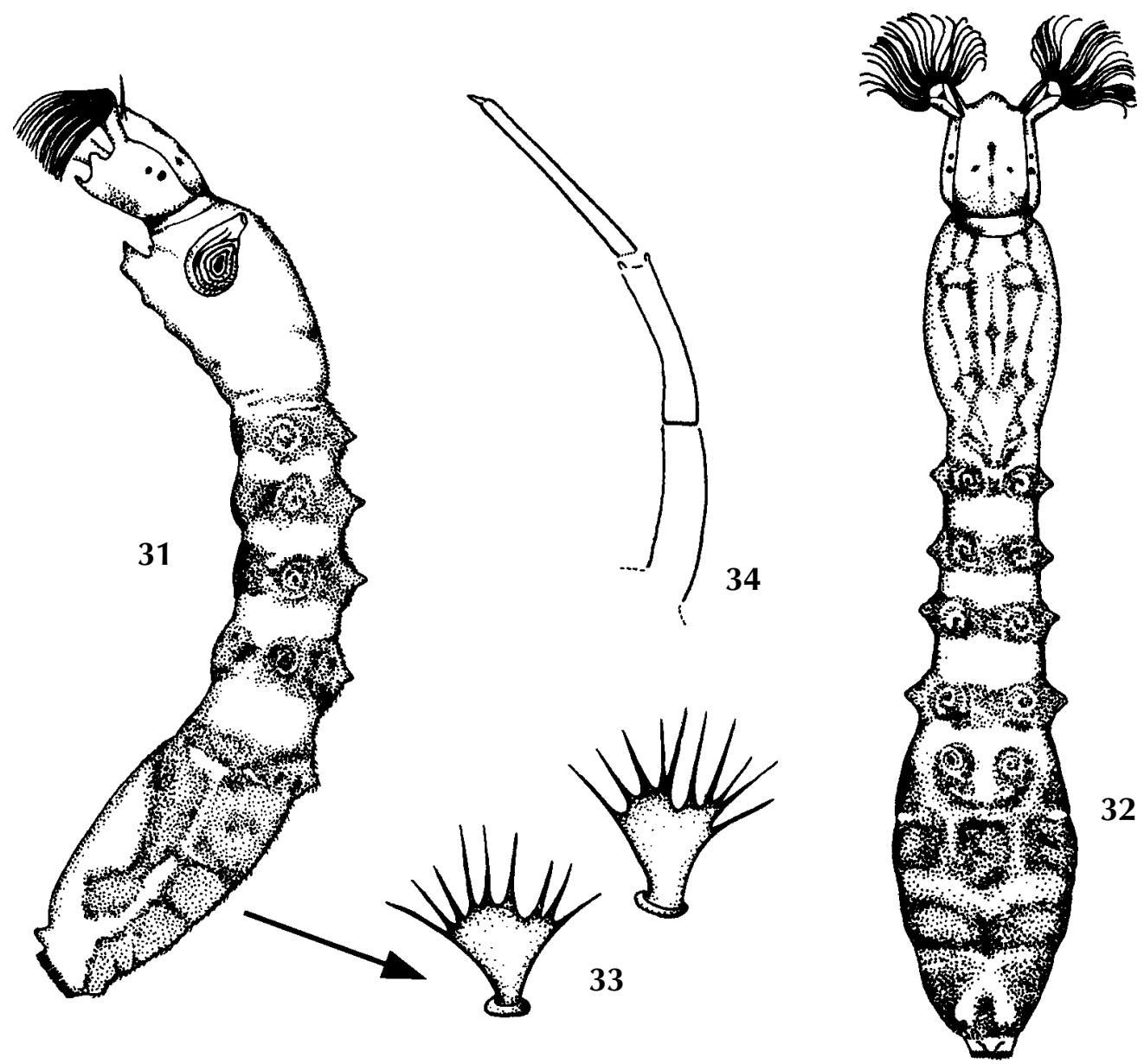

Simulium tergospinosum, larva. Larval habitus. Fig. 31: lateral view. Fig. 32: dorsal view. Fig. 33: multiply branched scale like setae from the body. Fig. 34: antenna 

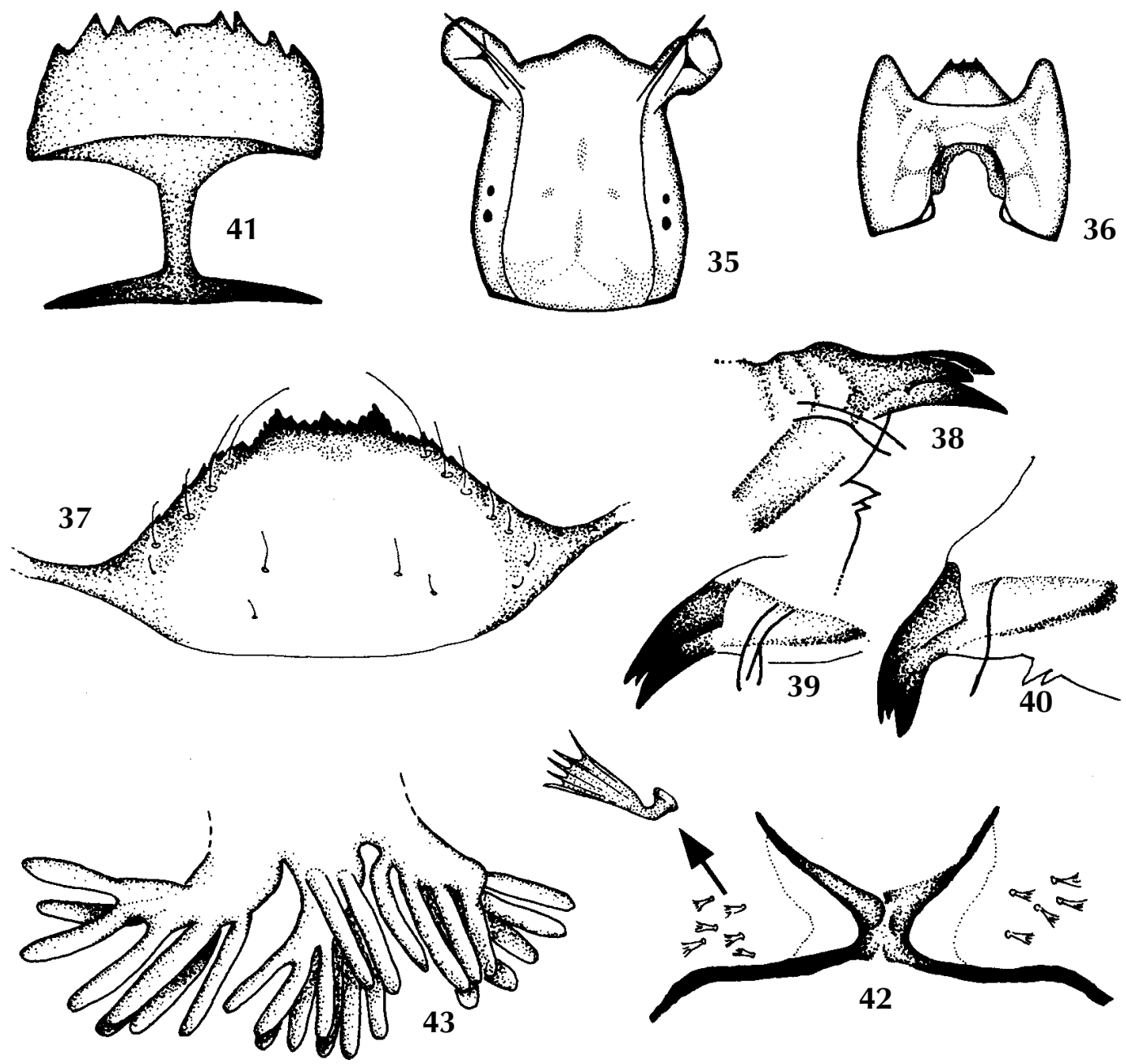

Simulium tergospinosum, larva. Head. Fig. 35: dorsal view. Fig. 36: ventral view, showing the pigmented subesophageal ganglion. Fig. 37: hypostoma. Figs 38-40: apex of mandible, showing lateral mandibular process variation. Fig. 41: labral sclerite. Fig. 42: anal sclerite, showing scale like setae. Fig. 43: anal papilla

described the male of $S$. siolii as having this ridge and two to three apical spines; $S$. tergospinosum has only one apical spine on the gonostylus. $S$. daltanhani also has a ridge on the gonostyle, but the ridge does not start at the base of the gonostyle. The male of this species has two to three apical spines on the gonostyle, and its scutum has no pattern like the one on S. tergospinosum, which has a scutum with cuneiform spots on the anterior region.

\section{REMARKS}

Females were collected biting people, during the field work, in the dry season (July1998 and August 1999), along water courses in Apuí county. Larvae and pupae were collected in one large blackwater, bedrock river (width $=60 \mathrm{~m}$; water tem- perature $=24^{\circ} \mathrm{C}, \mathrm{pH}=6.7$ and conductivity $=10.9$ $\mu \mathrm{S})$, with riffle areas and waterfalls. Larvae and pupae use as substrate fallen leaves and plants in the Podostemaceae family. In July 1998, S. tergospinosum larvae and pupae were collected together with $S$. exiguum species complex, $S$. cauchense, $S$. quadrifidum and Lutzsimulium simplicicolor Lutz; in August 1998, they were collected with $S$. exiguum species complex, $S$. cauchense, S. quadrifidum, L. simplicicolor and $S$. perflavum Roubaud. In May 1999, they were collected with L. simplicicolor and S. quadrifidum; in August 1999 they were collected with $S$. exiguum species complex, S. cauchense and S. quadrifidum. Larvae and pupae were abundant during the dry season (July-August 1998 and August 1999) when the water level of the river was low. 


\section{ACKNOWLEDGMENTS}

To Kiyoshi Nagaoka (Brazil Soka Gakkai International -BSGI), Charles Osawa (BSGI), Roberto Stieger (INPA) and Edilson (Projeto Lumiar-Apuí) for field support. Felipe F Xavier Filho made helpful collections in the study area. Deyse CQ Silva made many of the drawings presented here; Alexandre Kirowsky made the pupal abdomen drawing. Philip M Fearnside and Peter $\mathrm{H}$ Adler reviewed the manuscript.

\section{REFERENCES}

Coscarón S 1987. El género Simulium Latreille en la región Neotropical: Análisis de los grupos supraespecíficos, especies que los integran y distribución geográfica (Simuliidae, Diptera). Coleção Emilie Snethlage, MCT- CNPq, Belém, 111 pp.

Coscarón S, Coscarón-Arias C 1997. Cladistic analysis of the subgenera Inaequalium, Psaroniocompsa and Chirostilbia of the genus Simulium, with comments on their distribution (Diptera: Simuliidae). Rev Soc Entomol Argent 56: 109-121.

Crosskey RW 1999. First Update to the Taxonomic and Geographical Inventory of World Blackflies (Diptera: Simuliidae), Department of Entomology, The Natural History Museum, London, 13 pp.
Crosskey RW, Howard TM 1997. A New Taxonomic and Geografical Inventory of World Blackflies (Diptera:Simuliidae), Department of Entomology, The Natural History Museum, London, 144 pp.

Hamada N, Adler PH 1998. A new species of Simulium (Diptera: Simuliidae) from open areas in Central Amazonia, Brazil. Mem Inst Oswaldo Cruz 93: 317325.

Py-Daniel V 1988. Simuliidae (Diptera: Culicomorpha) no Brasil VI. Sobre Simulium (Psaroniocompsa) siolii sp.n., Simulium (P.) lourencoi sp.n. e Simulium (P.) damascenoi sp.n. Rev Saúde Púb 22: 292310.

Py-Daniel V 1989. Simuliidae (Diptera: Culicomorpha) no Brasil. X-Descrição de Simulium (Psaroniocompsa) guaporense sp. n. Rev Saúde Púb 23: 502508.

Ramírez-Pérez J, Peterson BV 1981. Estudio del complejo Simulium amazonicum-sanguineum en Venezuela. Descripción de tres nuevas especies. Bol Dir Malariol San Amb 21: 151-160.

Sabroski CW 1966. Mounting insects from alcohol. Bull Am Entomol Soc 12: 349.

Wygodzinsky P 1973. A black fly of the subgenus Simulium (Psaroniocompsa) (Simuliidae, Diptera) from the high Andes of Colombia. Amer Mus Novitates 2513: 1-11. 